\title{
EVALUATION OF SURFACE HYGIENE OF THE SURROUNDING OBJECTS IN A UNIVERSITY HOSPITAL
}

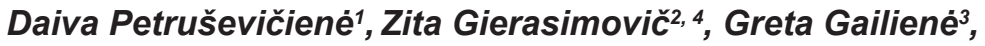 \\ Eglé Lendraitiené ${ }^{1}$, Sigitas Mingaila ${ }^{1}$ \\ Department of Rehabilitation, Medical Academy, Lithuanian University of Health Sciences ${ }^{1}$ \\ Vilnius University, Vilnius University Hospital Santariskiu Clinics ${ }^{2}$ \\ Institute of Microbiology and Virology, Lithuanian University of Health Sciences ${ }^{3}$ Department of Nursing \\ and Fundamentals of Internal Medicine, Faculty of Medicine, \\ Vilnius University
}

\begin{abstract}
Research background. Hygiene of the surfaces means a clean environment of a hospital, especially that of a patient, which consists of constant basic cleaning and disinfection. The registration, analysis and storage of data on cleaning, disinfecting the surrounding objects is a successful stage in ensuring clean surfaces. The registration of documents and the cleaning and disinfecting schedule help to determine the tender spots in the surface cleaning. It makes easy to establish the surface hygiene violations, participation of the nursing and auxiliary staff in disinfecting the surfaces, problems related to the surface disinfection, and make the analysis of the mistakes made easier.

The aim of the study. To assess a 2009-2011 hygienic preparation of medical surfaces, which have an effect on the transmission of the hospital-acquired infection, and the efficiency of the preventative measures.

Methods. The survey was conducted in university hospital in 2009-2011. To evaluate the surface hygiene of the environmental objects the test of the remains of biological contamination was chosen using the chemical means HemoCheck- $S^{\mathrm{Tm}}$. The accuracy of the test is $0.1 \mu \mathrm{q}$ of the remains of biological contamination on the surfaces under investigation. The results are evaluated by calculating the amount of denatured biological contamination from the highest concentration to 0 . The surface contamination is evaluated in points from " 0 " to " 5 ", where " 0 " is no contamination (medical surface is fully prepared for a procedure), and " 5 " is maximum contamination (100 $\mu \mathrm{q}$, maximum contamination shown by the HemoCheck- $\mathrm{S}^{\mathrm{TM}}$ test).

Results. Investigation shows that the surfaces belonging to the low-risk group are contaminated most heavily. The analysis of the investigations carried out during three years leads us to the conclusion that during the time of cleaning the surface, the staff fails to observe the sequence and do not change soft inventory (napkins) intended for cleaning. This is testified by presence of biological contamination in the low-risk group: switch-boards on the patients' beds, cupboards and drip mounts.

Conclusions. Insufficient hygiene of high, medium risk and often touched surfaces and surfaces of nursing measures was established. The inadequate preparation of the medical surfaces was most often made in the Intensive Care Intensive Therapy units.
\end{abstract}

Keywords: hygienic preparation; medical surfaces; the hospital-acquired infection.

\section{INTRODUCTION}

Hygiene of the surfaces means a clean environment of a hospital, especially that of a patient, which consists of constant basic cleaning and disinfection (Lithuanian hygiene norm HN 47-1:2010, 2010). Hygiene of the surfaces depends on the medical and nursing facilities used, as well as on the profile of the unit. Contamination of the medical and nursing facilities is a source of infection and its spreading (Cookson et al., 2009; DANMAP, 2010). Micro-organisms can be transmitted to a patient through the high-risk surfaces: medical equipment, surgical instruments, and during the time of carrying out endoscopies procedures, as well as through nursing facilities (Budek, 2010).

Previous investigations proved that the medical staff should be encouraged to tidy and look after the frequently touched surfaces very carefully, for example, to clean door handles, stethoscopes after using them to examine patients, cloth covers used for stethoscopes (Gilboy, Howard, 2008). The surveillance of medical surfaces and the frequency of its cleaning should be carried out in accordance with the Lithuanian Hygiene Norm HN 47:12010 (Lithuanian hygiene norm HN 47-1:2010, 2010).

Medical equipment (high-risk surfaces) used and handled by the staff should be cleaned regularly, in accordance with the cleaning schedule, though its supervision is complicated, for example, respiratory equipment, surgical instruments (D'Agata et al., 2008; Gilboy, Howard, 2008). Surfaces of medium risk, for example, nursing facilities (pots, urine collectors) are cleaned and disinfected in disinfecting sinks or cleaned and disinfected manually (Lithuanian hygiene norm HN 47-1:2010, 2010; Carling, Eck, 2010). It is not clear what degree of the surface contamination has an impact on the spread of infections at health care institutions; there is no uniform viewpoint of control of the surrounding surfaces (DANMAP, 2010). The nursing staff must ensure that only disinfected and clean medical equipment should be used and that clean and disinfected surrounding surfaces should be next to the patient.

The nursing staff must ensure that only disinfected, clean medical instruments and nursing facilities should be used and the surfaces surrounding the patient should be hygienic and sterile.

The transmission of microbes very often happens through staff members' hands and the surface of patients' surroundings (Pittet et al., 2006). The effective means to reduce the number of micro-organisms is to follow the standard surface cleaning and disinfecting procedures. 
The surrounding objects are divided into vertical and horizontal surfaces. Vertical surfaces of dressing and procedural rooms, for example, walls, floors, in transmitting hospital-acquired infection $(\mathrm{HI})$ and microorganisms are inessential as compared with the horizontal surfaces (Aiello et al., 2008; Budek, 2010). Horizontal surrounding work surfaces, dressing, procedural, drug tables and the surfaces, which are frequently used by the staff during their shifts, for example, door handles, wheelchairs, nursing facilities, can become dangerous sources of microbial contamination (Ayliffe et al, 2008; Brown et al., 2010). Upon touching these surfaces microbes can be transmitted to the nose, eyes, to the patient's skin, can get into a wound or on any other surface. This creates conditions not only for a patient but also for the staff to become infected (Aiken, 2012).

Disinfection is divided into disinfection of a high, medium and low level (Friedman, Newsom, 2007). Disinfection of the surfaces is one of the most important hygienic procedures in a hospital on which safety of patients and the medical stuff depends (Orosi et al., 2007). The aim of constant cleaning and disinfection of the premises is to put a stop to the spread of the agents of a disease in examining, treating and nursing the patient (Lithuanian hygiene norm HN 47-1:2010, 2010; Eckstein et al., 2007). The efficiency of disinfection of the surfaces depends on the properties, type, concentration, and stability of disinfectants, temperature of disinfectants and the ambient temperature, as well as on $\mathrm{pH}$ (Eckstein et al., 2007). The efficiency of cleaning depends on the contamination of the surfaces of the objects with biological substances and the number of agents of the disease, as well as their resistance to disinfectants (Costelloe et al., 2010). It has been established that frequent taking of samples from the surfaces makes the staff perform and maintain the surface hygiene and reduces the amount of contamination by up to four times (Cookson et al., 2009; DANMAP, 2010). There are different ways of determining the hygiene of work surfaces. Chemical, biological and monitoring ways are most often used (Dancer, 2009; Anderson et al., 2013). The principle of assessing cleanness of the surfaces is related to the modern risk management system of hospital-acquired infections, whose major principles are as follows: identification of the risk factors, introduction of the monitoring system, and application of corrective factors, in case of deviations, the establishment of testing procedures, and preparation of documents during safety assurance procedures. Qualitative assessment of clean surroundings would reveal the spread of pathogenic micro-organisms, would enable the risk of infection to be established (de Almeda e Borges et al., 2007).

The registration, analysis and storage of data on cleaning, disinfecting the surrounding objects is a successful stage of ensuring clean surfaces. The registration of documents and the cleaning and disinfecting schedule help to determine the tender spots in the surface cleaning, participation of the nursing and auxiliary staff in disinfecting the surfaces, problems related to the surface disinfection, and make the analysis of the mistakes made easier (Dancer, 2009; Carling et al., 2010).

Similar research was carried out by P. C. Carling et al. (2010), S. J. Dancer et al. (2009); however most of them concentrated on micro-biological test. Meanwhile, this survey emphasises the intensity of contamination without identifying the micro-organisms themselves. Having carried out the investigation, differences in cleaning practice and a decrease in the importance of monitoring surface cleaning were established in assessing and analysing hygiene of the surfaces (Otter et al., 2007; Weber et al., 2010). It is for the first time that the quality of cleaning and disinfecting surfaces of the medical environment has been assessed in Lithuanian. This type of survey has never been done in Lithuania before and its results will create conditions for the medical staff to reduce the effect of biological contamination of medical surfaces and improve their hygienic quality. The results will provide the medical staff with the possibility to reduce the effect of biological contamination and improve the quality of hygiene of the surfaces, as well as to eliminate the remains of biological contamination immediately.

The aim of the study was to assess a hygienic preparation of medical surfaces, which has an effect on the transmission of the hospital-acquired infection.

\section{METHODS}

The study was carried out in the university hospital (in 2009 - 948, in 2010 - 914, in 2011 - 911 patient beds) in Lithuania in 2009-2011.

The quality test has been conducted in 4 intensive care units, 14 surgery and 16 therapy units of university hospital. Medical surfaces were grouped taking into consideration a possible contamination into the following: inanimate objects of the environment with which the patients have no direct contact; things that do not penetrate the skin but are contaminated with virulent and spreading micro-organisms, things that penetrate into sterile tissues and cavities of the body.

The residues of biological contamination on 7 surfaces were assessed:

- Small-risk surfaces group (countertops, cabinets for storing medical and nursing instruments);
- Medium-risk surfaces group (respiratory secretion suckers, DPV moisturizers, medication injector, fluid collection containers, and inhalational holders);

- High-risk surfaces group (dripping, DPV appliances switches, infusion-meters, sterile packaging);

- Frequently touched environmental objects surfaces (door handles, bed panels, dripping mounts stand);

- Nursing measures (clean tanks, biological fluid collectors);

- Hand hygiene (soap, disinfectant holders, napkin holders);

- Equipment (DPV appliance reusable components, feeding pumps). 
To evaluate the surface hygiene of the environmental objects the test of the remains of biological contamination was chosen using the chemical means HemoCheck-S ${ }^{\text {TM }}$ test (according to EN ISO 15883). It is used to determine the remains of biological contamination (blood and other) on the surfaces. The accuracy of the test is $0.1 \mu \mathrm{g}$ of the remains of biological contamination on the surfaces under investigation. HemoCheck-S ${ }^{\mathrm{TM}}$ test is based on the establishment of the enzyme's reaction to a biological contamination. The results were evaluated by calculating the amount of denatured biological contamination from the highest concentration to 0 . The surface contamination is evaluated in points from " 0 " to " 5 ", where " 0 " is no contamination (medical surface is fully prepared for a procedure), and " 5 " is maximum contamination (100 $\mu \mathrm{g}$, maximum contamination shown by the HemoCheck-S ${ }^{\text {TM }}$ test). Taking into consideration the concentration, the results were evaluated by colour from intensive dark blue to yellowish, that is, from the highest concentration to 0 .

The data of the results of the quality of surface cleaning were verified again and made more exact twice; after that they were rearranged and analysed by means of statistical data processing packages. The surfaces, on which biological contamination was discovered, were marked " $1-5$ ", and if there was no contamination surfaces were marked "0".

We could not compare our data with those of other hospitals because we failed to discover any investigations into the surfaces, which determined the degree of contamination in applying a chemical test in Lithuania.
Ethical Considerations. Hygiene of medical surfaces was assessed having received permission from the Head of the treatment establishment. To ensure confidentiality, units of the hospital were divided into three groups and during the time of data analysis they were grouped into the intensive care, surgery and therapy profile units. This investigation was assessed prior to the procedures taking into consideration the standard surface cleaning plan and cleaning technology.

Statistical Data Analysis. The analysis of the surface data was carried out with the help of the following statistical programmes: Microsoft Excel, Statistical Package for Social Science SPSS for Windows 16.0 version, MedCalc for Windows 2011 complete statistical programme package.

Descriptive statistics were employed, and the characteristics of the samples were calculated: the average, the median, and the per cent. When comparing proportions between the evaluations, the binomial distribution criterion was applied. When establishing dependence between the surfaces groups the odds ratio (OR) of the Unit's risk was evaluated. The intervals of the odds ratio were calculated at $95 \%(95 \% \mathrm{Cl})$ and at the statistically significant $p$ level. The indicators were evaluated as statistically significant when $p<0.05$. The conclusions about the significance of the odds ratio were drawn on the basis of the lower limit of the confidence interval. The result was significant when the lower limit of the confidence interval was larger than one. The Fisher's exact test was applied to small samples.

\section{RESULTS}

Violations Mistakes of Surfaces Cleaning of the Environmental Objects. The data of total number of samples was analysed seeking to establish a spread of contaminated surfaces (Figure 1). In 2009, a total of 839 violations out of 16.087 samples $(5.19 \%)$ were established.

In 2010, violations were established in 799 out of 16.578 cases $(4.81 \%)$. The smallest number of violations $-2.64 \%$ (or 446 cases out of 16.834 samples) was established in 2011. If the results in 2009 and in 2010 did not differ significantly ( $p=0.062)$, when comparing them in 2011 with those in 2009 and in 2011 and with the results in 2010, the difference is great $\left(X^{2}=109.662\right.$, $p<0.01$; OR=1.86; 95\%, Cl 1.65-2.09; $p<0.01$ and $X^{2}=142.626, p<0.01 ;$ OR $=2.01 ; 95 \%, C l 1.77-2.26$; $p<0.01$, respectively). The supposition can be made that training in hygiene and the discussion of the investigation results during the study period could have had a positive impact on the obtained results.

In 2009-2011 each group out of 7 surfaces was rated to assess the residues of biological contamination six times a year. In 2009, mistakes in cleaning were found in the sphere of the surfaces that were frequently touched $29 \%$, and mistakes found in the sphere of small risk accounted for $23 \%$. 2.4 times $(p<0.05)$ more mistakes were made in the group of frequently touched surfaces than in the small risk group, 5.9 times $(p<0.05)$ more mistakes were made than in the group of nursing measures.
When investigating the efficiency of the cleaning process, the places where microbial contamination was the largest were established $(100 \mu \mathrm{g})$, maximum contamination shown by the HemoCheck-S ${ }^{\mathrm{TM}}$ test).

In 2010 the largest number of violations were made in the sphere of frequently touched surfaces $-26 \%$, then came the violations made in a small risk group and the group of nursing measures where the number of violations accounted for $19 \%$ in each group. A very similar tendency remained in 2011; violations in the sphere of frequently touched surfaces accounted for $28 \%$, those in the small risk groups constituted $28 \%$ and in the group of nursing measures they amounted to $16 \%$.

Contamination of the Surfaces of the Environmental Objects by Hospital Unit. Treating the Rehabilitation and Intensive Care Units as a referential group, we compared the surface contamination in other Units (disregarding the time period of the investigation). A statistically significant difference in the surfaces of the small risk group of the Intensive Care Units and the Unit of Therapy was established (OR $=2.58 ; 95 \%, \mathrm{Cl} 1.73-$ $3.84, p<0.05)$. The results in the group of frequently touched surfaces differed between the Rehabilitation and Intensive Care Units and the Surgery Unit $(O R=1.56$; $95 \%, \mathrm{Cl} 1.13-2.17, \mathrm{p}<0.05)$ and between the Intensive Care Unit and the Unit of Therapy (OR $=2.10 ; 95 \%, \mathrm{Cl}$ 1.47-2.9). 


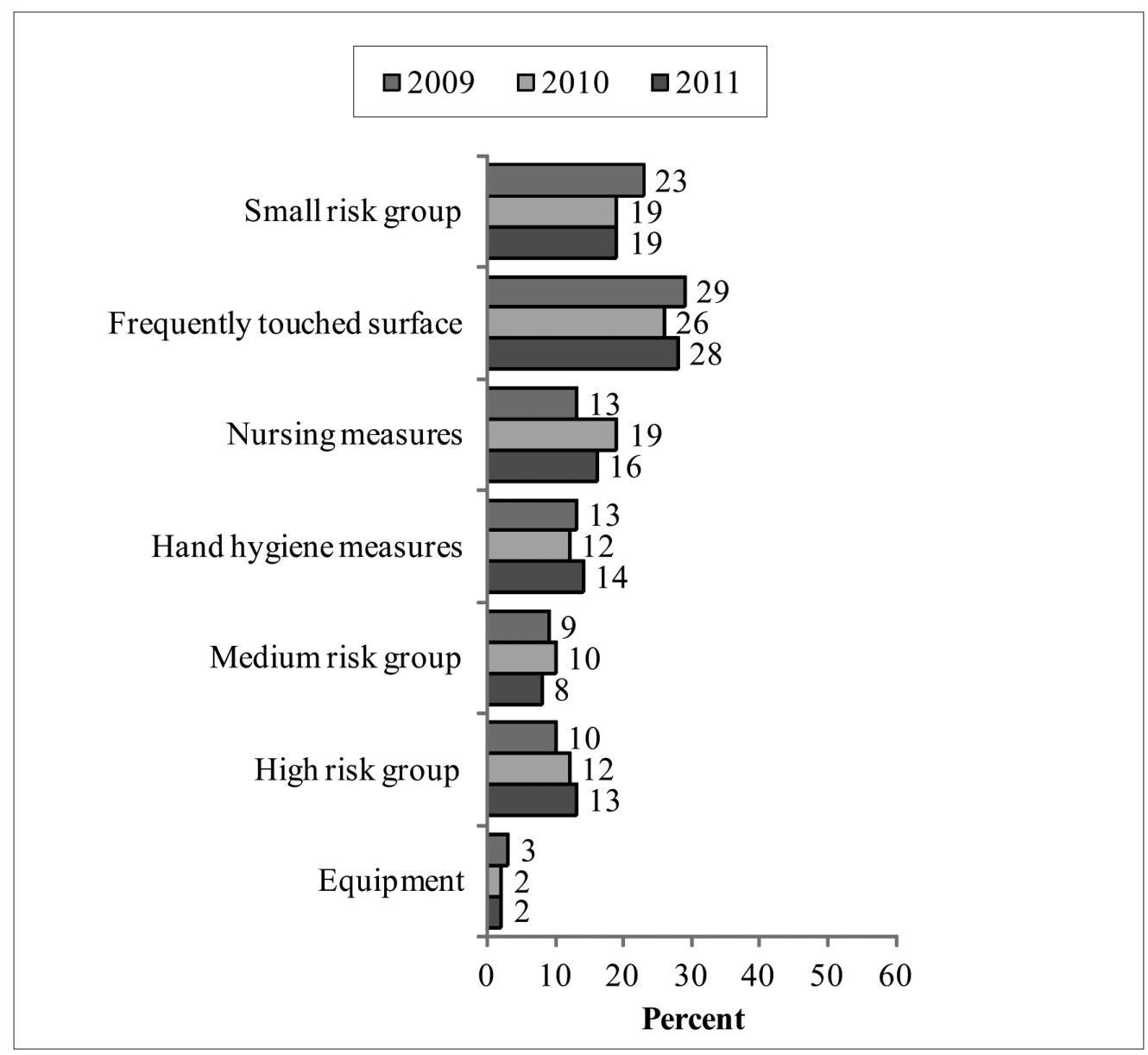

Figure 1. Distribution of violations of the surfaces cleaning of the environmental objects by risk groups

Similar tendencies were established when analysing the prevalence of surface contamination during certain time periods of the investigation. In 2009 and in 2010, the probability to establish contamination in the Surgery and Therapy Units was statistically significantly much greater than in the Rehabilitation and Intensive Care Units. However, in 2011, this difference was not statistically significant $(p=0.07)$ and the staff cleaned the surfaces more qualitatively in the high and medium risk groups (Table 1).

When analysing the year 2009 , the probability that the surface was cleaned in the wrong way if it belonged to the frequently touched surfaces or a medium or high risk group in the Rehabilitation and Intensive Care and
Surgery Units was statistically significant $(p<0.05)$. In the Rehabilitation and Intensive Care Units wrong cleaning of the surfaces was also plausible when evaluating the surfaces of the small risk group.

In 2010, a greater plausibility to find the improperly cleaned surfaces irrespective of the Unit in which the investigation was carried out (the Rehabilitation and Intensive Care, Surgery and Therapy Units $p<0.05$ ) was established in as many as three out of seven groups (small risk group, frequently touched surfaces and nursing measures). However, it should be noted that cleaning and hygienic supervision of nursing facilities was carried out adequately in all Units.

Table 1. Distribution of contamination the surfaces of the environmental objects in different units of the hospital in 2009-2011

\begin{tabular}{|c|c|c|c|c|c|c|}
\hline \multirow{2}{*}{$\begin{array}{l}\text { The established surface } \\
\text { contamination Yes and No }\end{array}$} & \multicolumn{2}{|c|}{2009} & \multicolumn{2}{|c|}{2010} & \multicolumn{2}{|c|}{2011} \\
\hline & $\begin{array}{c}\text { OR } \\
(95 \%, \mathrm{Cl})\end{array}$ & $p$ & $\begin{array}{c}\text { OR } \\
(95 \%, \mathrm{Cl})\end{array}$ & $p$ & $\begin{array}{c}\text { OR } \\
(95 \%, \mathrm{Cl})\end{array}$ & $p$ \\
\hline \multicolumn{7}{|l|}{ Unit } \\
\hline $\begin{array}{l}\text { Rehabilitation and Intensive } \\
\text { Care Units }\end{array}$ & $\begin{array}{c}0.69 \\
(0.69-0.71)\end{array}$ & $<0.001$ & $\begin{array}{c}0.70 \\
(0.69-0.71)\end{array}$ & $<0.001$ & $\begin{array}{c}0.95 \\
(0.94-0.97)\end{array}$ & 0.31 \\
\hline Surgery & $\begin{array}{c}0.93 \\
(0.92-0.95)\end{array}$ & 0.17 & $\begin{array}{c}0.80 \\
(0.80-0.82)\end{array}$ & 0.001 & $\begin{array}{c}0.86 \\
(0.86-0.88)\end{array}$ & 0.07 \\
\hline Therapy & $\begin{array}{c}1.66 \\
(1.64-1.69)\end{array}$ & $<0.001$ & $\begin{array}{c}2.02 \\
(2.00-2.06)\end{array}$ & $<0.001$ & $\begin{array}{c}1.30 \\
(1.29-1.32)\end{array}$ & 0.01 \\
\hline
\end{tabular}

Note. ${ }^{*}-$ statistically significant $p<0.05$. 


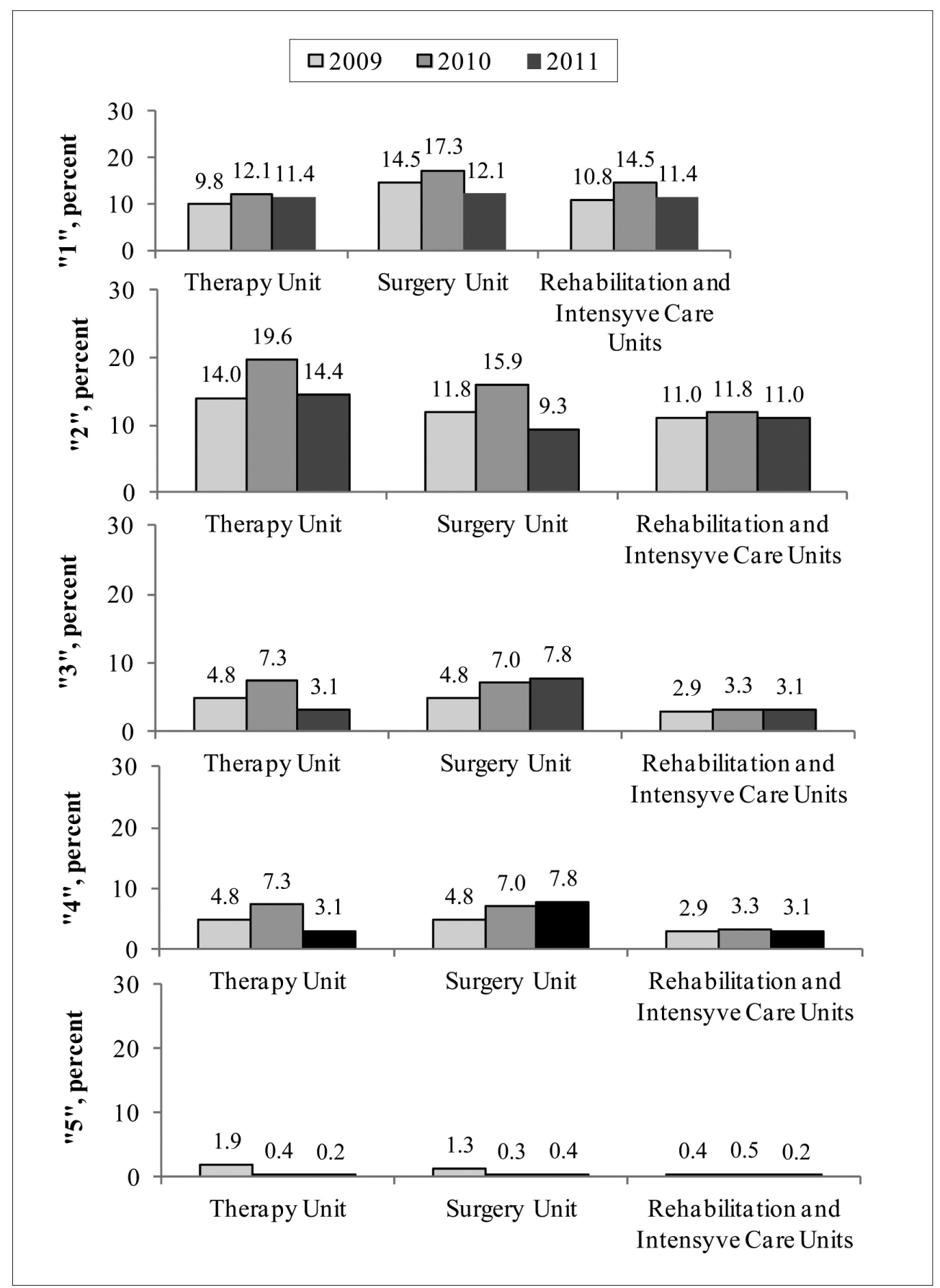

Figure 2. Distribution of the discovered contamination of the surfaces of the environmental objects in the therapy Unit, Surgery Unit, Rehabilitation und Intensive Care Units

When analysing the 2011 data it can be stated that in the Rehabilitation and Intensive Care Units in six out of seven groups a greater probability of improper cleaning of the surfaces $(p<0.05)$ was established: this was not characteristic of the equipment group only because the equipment was properly cleaned during the entire time of carrying out the investigation (2009-2011).

The situation was better in the Surgery and Therapy Units and the probability to establish an increased surface contamination of the environmental objects was smaller in the low risk and nursing measures groups ( $p>0.05)$.
The surfaces of the environmental objects in the Units of the hospital were evaluated by contamination points: from "1" - a slightly contaminated surface, to " 5 " a severely contaminated surface.

The distribution of the mistakes made by the staff in cleaning the surface of the objects, taking into consideration the contamination point depended on the time of the investigation and the Unit being investigated and is indicated in Fig. 2. When analysing the data obtained one can see that irrespective of the Unit being evaluated, surfaces of slight and very slight contamination prevailed. 
One of the preventive measures of hospital-acquired infections is maintaining hygiene of the surfaces (Carling, Bartley, 2010). In assessing hygiene of three-year-old surrounding objects during the investigation the average contamination $(4.2 \%)$ was established. In our case, in the course of three years, the greatest contamination of the surfaces, accounting for "1"-"2" points, was determined in the groups of most frequently touched surfaces and low-risk surfaces. It turned out that prior to cleaning the surfaces, $(31.5 \%)$ clean floor mobs and napkins were kept wet.

The surface monitoring method shows that the surface contamination next to a patient is heavy, the surfaces are not properly cleaned and their microbial contamination is higher. Disinfectants used for cleaning reduced the degree of contamination by several times, especially they reduced contamination in the groups of frequently touched and low-risk surfaces; however, when the cleaning inventory as wet, disinfecting chemical substance was diluted and low surface cleaning efficiency was determined (Budek, 2010; Lithuanian hygiene norm HN 47 1:2010, 2010).

Our investigation carried out between 2009 and 2010 determined that contamination of the group of frequently touched surfaces was 2.4 times higher than contamination of the surfaces in the low-risk group. A similar tendency for contamination of the surrounding objects was observed in 2011; however, as compared with the data presented in literature, a higher microbial contamination of the frequently touched surfaces in the surroundings of patients is indicated (Gacouin et al., 2009; Lithuanian hygiene norm HN 47-1:2010, 2010; Warnes et al., 2010).

It was established that chemical substances used for cleaning reduced the surface contamination by up to $36 \%$. They are more efficient than fast cleaning of the surfaces by spraying them (Department of Health. The Health Act, 2006). A wet way of two systems of the surface cleaning is recommended to be used in Lithuanian hospitals (Lithuanian hygiene norm HN 47-1:2010, 2010). During our investigation it was established that cleaning of frequently touched surfaces by means of spraying was performed without taking into account biological contamination of the surfaces and their size. In 2009-2011, during our investigation, in all cases of assessing the surfaces, a wet way of two systems of the surface cleaning was used and fast disinfection was applied to more quarter per cent of the surfaces of small size. In 2009-2011, there were as much as almost $10 \%$ of cases when fast disinfection was applied to the surfaces of large size. In 2009, that fast surface disinfection by spraying was quite often applied to disinfect the surfaces of large size $(6.6 \%)$, and in 2011 , cases of disinfection of the surfaces of large size by spraying decreased by more than two times as compared with that in 2010.

From 2009 to 2011 contamination of the surfaces belonging to the low-risk group decreased by more than two times, contamination of the surfaces belonging to the group of medium risk decreased twofold. Contamination of the frequently touched surfaces and the surfaces belonging to the high-risk group decreased by 2 greatly times, the number of mistakes made in cleaning the nursing facilities and the surfaces belonging to the medium-risk group decreased by 1.6 times. We could not compare our data with those of other hospitals because we failed to discover any investigations into the surfaces, which determined the degree of contamination in applying a chemical test in Lithuania. It is thought that such preventative measures as periodical training of the staff ( 6 times per year) emphasising the importance of hygiene of the surfaces, a distribution of a possible biological contamination in the patients' environment, mastering of cleaning technology and the analysis of the mistakes made in maintaining the surface hygiene helped to reduce a biological contamination of the surfaces of environmental objects in 2011 as compared with that in 2009-2010.

The analysis of the results revealed five significant differences in the distribution of contamination of the surrounding objects were established. These are groups of low-risk, frequently touched surfaces, nursing and highrisk surface groups in which mistakes made by the staff in cleaning the surfaces were found. However, there were always more violations in those units where no hospitalacquired infection was discovered and where the stuff felt safer in performing penetration procedures.

The data of our investigation confirms that insufficient frequency of cleaning frequently touched surfaces once per day has a hygienic gap that encourages the growth of bacteria and a further transmission of contamination.

In the majority of cases it was determined that lowrisk surfaces were contaminated most heavily (Carling et al., 2010). Quantitative microbiological and chemical data help to assess contamination of the surfaces, its reasons and to select preventive measures of hospitalacquired infection more carefully (Carling et al., 2010; Carling et al., 2013).

The study shows that the surfaces belonging to the low-risk group are contaminated most heavily. This coincides with the results presented by other researchers (Boyce, 2007; Dancer et al., 2008; White et al., 2008). The analysis of the investigations carried out during three years leads us to the conclusion that during the time of cleaning the surfaces the staff fails to observe the sequence and do not change soft inventory (napkins) intended for cleaning. This is testified to by presence of biological contamination in the low-risk group: switch-boards on the patients' beds, cupboards and drip mounts. In 2009 , the amount of contamination in the low-risk group $(23 \%)$ was 1.2 times higher than that in 2011 . The greatest frequency of contamination of frequently touched surfaces in 2009-2011 was determined on the following surfaces: door handles, switches, nursing facilities. The assessment of cleaning the surface contamination for three years helped "clean" and "unclean" surfaces to be established and the mistakes made by the staff during cleaning to be elucidated.

It was determined that the heaviest contamination accumulated in the nursing facilities and liquid soap dispensers, napkin boxes, in the group of frequently tou- 
ched surfaces. This shows the biological contamination transmission mechanism when microbes are left on the surfaces by the hands of the nursing staff; the group of low-risk surfaces is touched most often. The way of transmitting contamination - the staff's hands - surfaces - helps the importance of hygiene of the surfaces to be understood (Bartley, 2000; Kundrapu et al., 2012).

The results of our investigation revealed a slower spread of hospital-acquired infection but a general spread of hospital-acquired infections during the period under analysis in those units of the hospital where patients were treated for a longer time remained stable. It is thought that it is necessary to look for other means of reducing hospital-acquired infection, for example, to apply singleuse covers for purulent surgeries, to standardise kits of medical instruments, to record monitoring of nursing services provided to the patients who undergo treatment in hospital for a long time, to analyse the mistakes made by the staff. During our investigation it was determined that a higher probability of catching the hospital-acquired infection was related to the risk of applying penetration instruments (vascular, urinal catheters, surgical drains), therefore it is recommended to devote more attention to hygiene of these instruments, to develop skills of hand hygiene of the staff in performing penetration procedures and to pay attention to preparing the patients for the intervention procedure.

When analysing the data of the investigation the supposition is made that hygiene of the staff's hands and the surfaces of the surrounding objects, failure to follow the rules of applying antiseptic detergent is an important cause of hospital-acquired infection and regular training of the staff enables positive results to be achieved.

\section{CONCLUSIONS}

Mistakes discovered in hygienic care of surfaces. Insufficient hygiene of high, medium risk and often touched surfaces and surfaces of nursing measures was established. The inadequate preparation of the medical surfaces was most often made in the Intensive Care Intensive Therapy units.

Evaluating the distribution of contamination on medical surfaces it is advisable to further the studies of these surface groups: high-risk, often touched, nursing, equipment surfaces groups.
The preventative measures applied had a positive effect on the supervision of the surfaces of environmental objects penetrating into sterile tissues and cavities of the body.

Acknowledgments. We express my most sincere thanks to the employees of Vilnius University Hospital for their participation in the investigation and their support.

\section{REFERENCES}

Aiello, A. E., Coulborn, R. M., Perez, V., Larson, E. L. (2008). Effect of hand hygiene on infectious disease risk in the community setting: A meta-analysis. American Journal of Public Health, 98, 1372-1381.

Aiken, Z. A. (2012). Measuring the Susceptibility and Adhesion of Microorganisms to Light-Activated Antimicrobial Surfaces: Doctoral thesis. London: University College.

Anderson, D. J., Gergen, M. F., Smathers, E. et al. (2013). Decontamination of targeted pathogens from patient rooms using an automated ultraviolet-C-emitting device. Infection Control and Hospital Epidemiology, 34(5), 466-471. doi: 10.1086/670215

Ayliffe, G. A. J., Fraise, A. P., Geddes, A. M., Mitchell, K. (2008). Control of Hospital Infection: A Practical Handbook. Cleaning of Isolation Rooms. London: Arnold. P. 34-36.

Bartley, J. M. (2000). APIC state-of-the-art report: The role of infection control during construction in health care facilities. American Journal of Infection Control (AJIC), 28, 156-169.

Boyce, J. M. (2007). Environmental contamination makes an important contribution to hospital infection. Journal of Hospital Infection, 65(Suppl. 2), 50-54.

Brown, E., Eder, A. R., Thompson, K. M. (2010). Do surface and cleaning chemistries interfere with ATP measurement systems for monitoring patient room hygiene? Journal of Hospital Infection, 74, 193-195.

Budek, W. (2010). Operational block as a high inflectional risk place a warning against hospital infections. In XXI Century Nursing. Lublin Medical University. , P. 32-33, 69-74.

Carling, P. C., Bartley, J. M. (2010). Evaluating hygienic cleaning in health care settings: What you do not know can harm your patients. American Journal of Infection Control, 38, S41-S50.

Carling, P. C., Eck, E. K. (2010). Achieving sustained improvement in environmental hygiene using coordinated benchmarking in 12 hospitals. SHEA fifth Decennial Meeting. Atlanta GA (pp. 18-22).
Carling, P. C., Huang, S. S. (2013). Improving health care environmental cleaning and disinfection: Current and evolving issues. Infection Control and Hospital Epidemiology, 34, 507-513.

Carling, P. C., Po, J. L., Bartley, J., Herwaldt, L. (2010). Health care Environmental Hygiene Identifying opportunities to. Improve Environmental Hygiene in multiple Health care settings. SHEA Fifth Decennial Meeting. Atlanta, GA, March (pp. 18-22).

Cookson, B., Mathai, E., Allegranzi, B. et al. (2009). Comparison of national and subnational guidelines for hand hygiene. Journal of Hospital Infection, 72, 202-210.

Costelloe, C., Metcalfe, C., Lovering, A., Mant, D., Hay, A. D. (2010). Effect of antibiotic prescribing in primary care on antimicrobial resistance in individual patients: Systematic review and meta-analysis. British Medical Journal (BMJ), 340 (c), 2096.

D'Agata, E., Mitchell, S. L. (2008). Patterns of antimicrobial use among nursing home residents with advanced dementia. Archives of Internal Medicine, 168, 357-362.

Dancer, S. J. (2009). The role of environmental cleaning in the control of hospital-acquired infection. Department of Environmental Conservation (DEC), 73(4), 378-385. doi: 10.1016/j.jhin.2009.03.30

Dancer, S. J., White, L. F., Lamb, J., Girvon, E. K., Robertson, C. (2009). Measuring the effect of enhanced cleaning in a UK hospital: A prospective cross-over study. BMC Medicine, 7, 28.

Dancer, S. J., White, L. F., Robertson, C. (2008). Monitoring environmental cleanlinness on two surgical wards. International Journal of Environmental and Health Research, 18(5), 357-364.

DANMAP. (2010). Use of antimicrobial agents and occurrence of antimicrobial resistance in bacteria from food animals, food and humans in Denmark. Retrieved from: URL: http://edit.ssi.dk/sitecore/ shell//Controls/Rich\%20Text\%20Editor/ /media/1D3AE61B306E4356 9bfa676DAB33678F.ashx. 
De Almeida e Borges, L. F., Silva, B. L., Gontijo, Filho, P. P. (2007). Hand washing: Changes in the skin flora. American Journal of Infection Control, 35(6), 417-420.

Department of Health. The Health Act. (2006). Code of practice for the prevention and control of health care associated infections. London: $\mathrm{DH}$.

Eckstein, B. C., Adams, D. A., Eckstein, E. C. et al. (2007). Reduction of Clostridium Difficile and vancomycin-resistant Enterococcus contamination of environmental surfaces after an intervention to improve cleaning methods. BMC Infections Diseases, 7, 61. doi:10.1186/14712334-7-61

Friedman, C., Newsom, S. W. B. (2007). IFIC Basic Concepts of Infection Control. 3-rd edition. Portadown: International Federation of Infection Control. P. 65-74.

Gacouin, A., Barbarot, N., Camus, C. et al. (2009). Late-onset ventilator-associated pneumonia in nontrauma intensive care unit patients. Anesthesia and Analgesia, 109, 1584-1590.

Gilboy, N., Howard, P. K. (2008). Compliance with hand hygiene guidelines. Advanced Emergency Nursing Journal, 30, 193-200.

Kundrapu, S., Sunkesula, V., Jury, L. A., Sitzlar, B. M., Donskey, C. J. (2012). Daily disinfection of high-touch surfaces in isolation rooms to reduce contamination of health care workers' hands. Infection Control and Hospital Epidemiology, 33(10), 1039-1042.

Lithuanian hygiene norm HN 47-1:2010 "Health care facilities. Infection

Orosi, P., Farkas, A., Berkes, I., Salnẻ, N. G. et al. (2007). Surveillance results of nosocomial infections of the ICU in Kenézy Hospital, based on two years. ORV Hetil, 148, 1469-1473.

Otter, J. A., Cummins, M., Ahmad, F., van Tonder, C., Drabu, Y. J. (2007). Assessing the biological efficacy and rate of recontamination following hydrogen peroxide vapour decontamination. Epub [2007 09 19]. Journal of Hospital Infection, 67(2), 182-188.

Pittet, D., Allegranzi, B., Sax, H. et al. (2006). WHO Global Patient Safety Challenge, World Alliance for Patient Safety. Evidence-based model for hand transmission during patient care and the role of improved practices. Lancet Infections Diseases, 6, 641-652.

Warnes, S. L., Green, S. M., Michels, H. T., Keevil, C. W. (2010). Biocidal efficacy of copper alloys against pathogenic enterococci involves degradation of genomic and plasmid DNAs. Applied and Environmental Microbiology, 76, 5390-5401.

Weber, D. J., Rutala, W. A., Miller, M. B., Huslage, K., SickbertBennett, E. (2010). Role of hospital surfaces in the transmission of emerging health care-associated pathogens: Norovirus, Clostridium difficile, and Acinetobacter species. American Journal of Infection Control, 38(5 Suppl. 1), S25-S33. doi: 10.1016/j.ajic.2010.04.196

White, L. F., Dancer, S. J., Robertson, C., McDonald, J. (2008). Are hygiene standards useful in assessing infection risk? American Journal

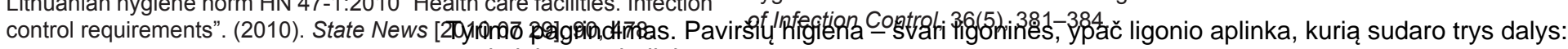
nuolatinis, pagrindinis valymas ir dezinfekcija. Aplinkos valymo, dezinfekcijos duomenų registravimas, analizè ir

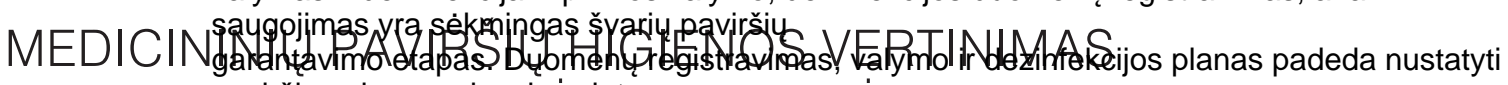

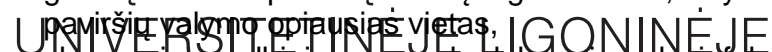
slaugos ir pagallbinio personato daly vavimą dezintekuojant paviršius, su paviršiu dezinfekcija susijusias problemas, analizuoti

Daiva Rlatdaševičiené1, Zita Gierasimovič2, 4 , Greta Gailiené ${ }^{3}$,

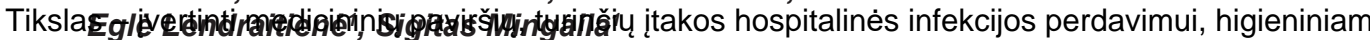
paruošimui ir profilaktinių

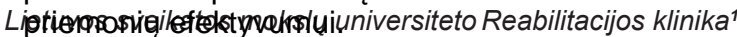

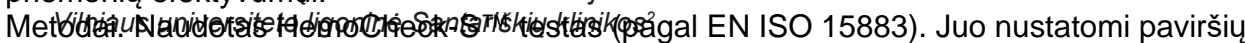

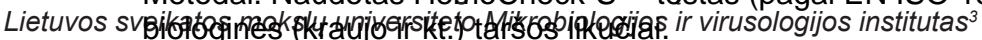

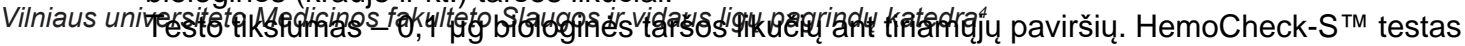
pagristas fermento reakcijos i kraują nustatymu. Rezultałąijvertinamj po 30 sekundžių, remiantis denatūruoto kraujo kiekiu nuo aukščiausios koncentracijos iki 0 , t. y. iš

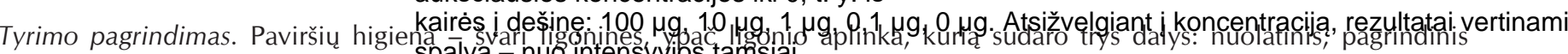

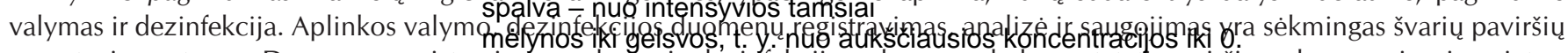

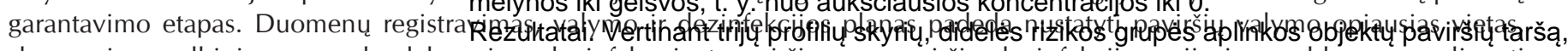

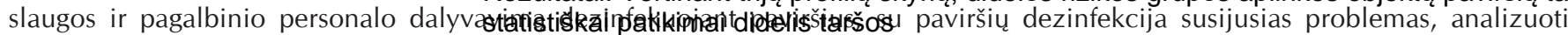
klaidas. $\quad$ kiekis nustatytas $2009 \mathrm{~m}$. $(\mathrm{OR}(2009)=1,94 ; 95 \% \mathrm{Pl} 1,38-2,72 ; \mathrm{p}=0,00)$ ir $2010 \mathrm{~m}$. (OR(2010) =

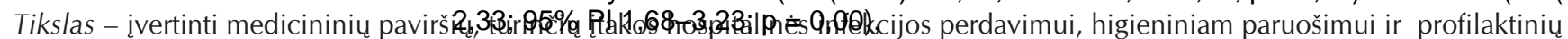
priemonių efektyvumui. palyginti su $2011 \mathrm{~m}$. Visais tyrimo metais įrangos grupès paviršiai buvo tinkamai prižiūrimi.

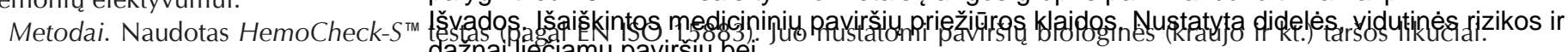

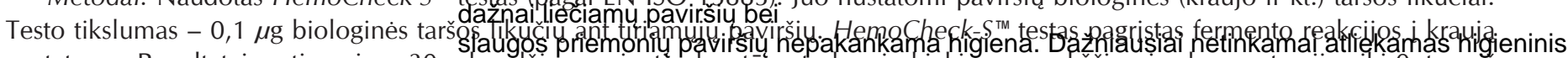

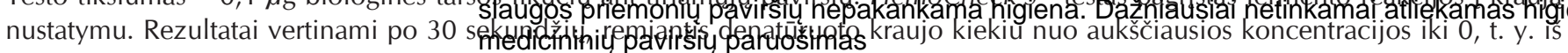
kairès i dešinę: $100 \mu \mathrm{g}, 10 \mu \mathrm{g}, 1 \mu \mathrm{g}, 0,1$ reănîn

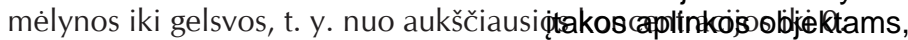

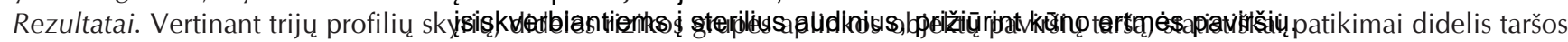

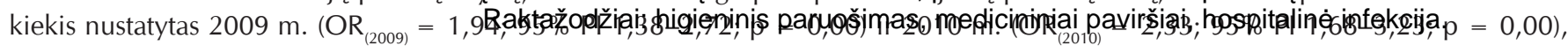
palyginti su $2011 \mathrm{~m}$. Visais tyrimo metais įrangos grupès paviršiai buvo tinkamai prižiūrimi.

Išvados. Išaiškintos medicininių paviršių priežiūros klaidos. Nustatyta didelès, vidutinès rizikos ir dažnai liečiamų paviršių bei slaugos priemonių paviršių nepakankama higiena. Dažniausiai netinkamai atliekamas higieninis medicininių paviršių paruošimas reanimacijos ir intensyviosios terapijos skyriuose. Taikytos profilaktinès priemonès turèjo teigiamos įtakos aplinkos objektams, įsiskverbiantiems ì sterilius audinius, prižiūrint kūno ertmès paviršių.

Raktažodžiai: higieninis paruošimas, medicininiai paviršiai, hospitalinė infekcija. 